\title{
Study of Reproductive Health of Young Women in the District of Jombang
}

\author{
Ita Mardiani Zain* \\ Geography Education Department \\ Faculty of Social Sciences and Law, \\ Universitas Negeri Surabaya \\ Surabaya, East Java, Indonesia \\ itazain@unesa.ac.id \\ Arni Ayuni \\ Graduate Student of Geography \\ Education Department \\ Faculty of Social Sciences and Law, \\ Universitas Negeri Surabaya \\ Surabaya, East Java, Indonesia \\ arniayuni@gmail.com
}

\author{
Wiwik Sri Utami \\ Geography Education Department \\ Faculty of Social Sciences and Law, \\ Universitas Negeri Surabaya \\ Surabaya, East Java, Indonesia \\ wiwikutami@unesa.ac.id
}

\author{
Kuspriyanto \\ Geography Education Department \\ Faculty of Social Sciences and Law \\ Universitas Negeri Surabaya \\ Surabaya, East Java, Indonesia \\ kuspriyanto@unesa.ac.id
}

\begin{abstract}
Non-governmental organization Sebaya youth centre Jombang, in 2017 handled various problems involving adolescents, including 185 unwanted pregnancies, the number of sexually transmitted diseases as many as 13 cases, there were 4 teenagers who had abortions. The purpose of this study is to find out how knowledge, attitudes, parental education level parental communication, and parenting patterns of adolescent reproductive health behaviours and which factors are most influential. Chi-Square test results indicate that knowledge influences reproductive health behaviour with sig. knowledge $p<\alpha(0,000<0.05)$, Relative Risk (RR) value of 1.57 which means that respondents who have less knowledge are more likely to behave less than $\mathbf{1 . 5 7}$ more than those who have good knowledge. The results of the Multiple Logistic Regression test show that the most influential is knowledge ( $p$ sig. $=0.003)$. The Odd Ratio $($ OR) value is 0.413 , which means that respondents with less knowledge have the risk or the possibility of good behaviour by 0.413 times compared to respondents who have good knowledge, in other words respondents who have good knowledge have the possibility of good behaviour by $1 / 0.413=2.42$ times compared respondents with insufficient knowledge. Views and documentation. Data analysis techniques with scoring techniques.
\end{abstract}

Keywords: adolescents, reproductive health, knowledges, attitude, communication with parents, parental eduction level, parenting style, behavior

\section{INTRODUCTION}

Indonesia is one of the countries that agreed with the results of the 1994 International Conference on Population and Development (ICPD) in Cairo, this conference focuses on reproductive health which prioritizes health with the aim of fulfilling individual reproductive health rights in managing population and development issues. There was a broad shift that initially managed population and development issues, population control and fertility reduction through family planning to reproductive health and reproductive rights. The scope of reproductive health services consists of maternal and child health, family planning, prevention and treatment of sexually transmitted diseases including HIV / AIDS, adolescent reproductive health, prevention and management of abortion, infertility, elderly reproductive health, early detection of reproductive tract cancer age and problems other reproductive health such as sexual violence. [1]

Indonesian people have not yet had the same access in terms of their reproductive health, it can be concluded by looking at the still high maternal mortality rate (MMR), high teenage pregnancy rates, low use of contraception. Following the agreement, various efforts to improve reproductive health services, one of which is since years 2002 Ministry of Health develops the application of integrated reproductive health services (PKRT), the contents of this program are more or less the same as the scope of reproductive health services. General description of reproductive health services in Indonesia, maternal and child health by providing personnel and hospital and puskesmas health facilities, family planning by conducting acceptors and increasing IEC advocacy, adolescent reproductive health by developing adolescent health programs namely Youth Health Care Services (PKPR) located at the health center.

Based on data obtained from the Community Institution of Sebaya Youth Center, Jombang Regency, in 2017 handled various problems involving adolescents, including 185 unwanted pregnancies, the number of sexually transmitted diseases as many as 13 cases, there were 4 teenagers who had abortions.

\section{Automated assumption generation}

Based on data obtained from the Institute Sebaya Youth Centre, Jombang Regency, in 2017 dealing with a variety of problems involving teens, among others, there are 185 pregnancies unwanted, number of sexually transmitted diseases as many as 13 cases, there were 4 teenagers who did abortion. Based on some of these things researchers interested in doing research on health adolescent reproduction in Jombang with the title "Adolescent Girls' Reproductive Health Study Jombang Regency ". The purpose of this study is to find out adolescent reproductive health Jombang Regency women. 


\section{METHOD}

This type of research used in this study is a type of survey research using cross sectional research design which is a study in which data or information regarding variables are collected at the same time which means that each subject is only measured in one measurement. Data collection uses interviews and documentation. The population in this study were 2,145 unmarried women of 12-21 years with a sample of 200 respondents. Data sources used in the form of primary data and secondary data. Primary data were obtained from observations and surveys, while secondary data were obtained from the Central Statistics Agency of Jombang Regency, Jombang Regency Health Office, Jombang Regency Population Office.

\section{RESULTS AND DISCUSSION}

Respondents know that the event of blood loss called menstruation and knowledge the least known by respondents is the type of tubectomy contraception as many as 144 or $72 \%$ respondent. Attitudes of respondents towards reproductive health as many as 143 respondents or $71.5 \%$ expressed strongly agree with the statement of abortion is very important dangerous. Statement of attitude whether the respondent agrees with a pregnant teenager out of wedlock and will have an abortion get a disagree response from respondents as many as 127 people or $63.5 \%$ and those who give a very disagreeing response as many as $29.5 \%$ or 59 respondents.

Behavior of respondents regarding reproductive health, including behavior or ways of dating adolescents and behavior or ways to maintain adolescent reproductive health shows that ways of dating adolescents shows as many as 123 respondents or $61.5 \%$ states have joined hands with their partner. All respondents in this study stated that they never had sexual relations using or not using contraceptives during sexual intercourse.

Education level of people the highest number of respondents is 88 senior high schools respondents or $44 \%$ and the least is elementary school level with 26 respondents or $13 \%$, it can be interpreted that the education of the respondent's parents is in accordance with the program determined by the government and is classified in secondary education. Respondent communication with parents with democratic parenting as many as 93 people with a percentage of $46.5 \%$, while the authoritarian parenting as many as 107 people with or $53.5 \%$.

\section{A. Effect of Knowledge on adolescent reproductive health behaviors}

Knowledge has a significant influence on adolescent reproductive health behavior as evidenced by the results of the chi-square test it can be seen the value of $p=0,000$ and the value of $\chi^{2}=18,414$ by using a degree of error $(\alpha)$ of 0.05 , then $\mathrm{p}<\alpha(0,000<0.05)$. The results of this study indicate that the Relative Risk (RR) value of 1.57 which means that respondents who have less knowledge are likely to behave less 1.57 more than those who have good knowledge. The results of this study are supported by the results of [2] that there is a significant influence between knowledge and behavior with a value of $p=0.01$, the results of the study stated that respondents who have less knowledge have risk behaviors $36.2 \%$ greater than who have good knowledge of $14.5 \%$.

The difference in the results of this study with other studies shows that the knowledge possessed by one individual with other individuals is different, differences in the level of education possessed by individuals are usually influenced by socioeconomic, tradition or culture, religion, and information media, according to the opinion of [3] it is concluded that knowledge is influenced by a person's experience which then the experience is expressed, believed and then gives rise to, motivation and other factors that influence knowledge namely the environment both physical and non-physical and socio-cultural, the source of knowledge acquired by each individual most of them get from the sense of hearing and the sense of sight. The results of knowledge research affect the behavior of reproductive health seen from a high sense of curiosity of adolescents to find information about reproductive health and try to do or understand their reproductive health, coupled with counseling conducted by health workers, although in a rare period of time.

\section{B. The influence of attitudes on adolescent reroductive health behaviors}

Attitudes toward reproductive health behavior do not show any influence, this has been proven by the results of the chi-square test that the value of $p=0.590$ and the value of $=^{2}=0.290$ using the degree of error $(\alpha)$ of 0.05 , then $p$ $<\alpha(0.290>0.05)$, in line with [2], there was no significant effect between attitude and reproductive health behavior with a value of $p=0.52$. According to Mednick, Higgins in [4] that attitudes are formed influenced by 3 factors, namely (1) social influences such as values and norms, (2) character of individual personalities, (3) information obtained by individuals. This opinion is supported by[5], that attitudes about reproductive health are shown by being able to handle and prevent early on reproductive health problems.

\section{Effect of parental educational on adolescent reproductive health behaviors}

The results of the study stated that the rate parental education on reproductive health behavior does not show any influence, this has been proven by the results of the chisquare test that $\mathrm{p}=0.861$ and value $=0.31$ by using a degree of error $(\alpha)$ of 0.05 , then $p<\alpha(0.861>0.05)$. The results showed that the average education level of respondents was classified as secondary education, in accordance with government programs that require a minimum of 9 years of study. The results of this study are different from the results of [6] stating that there is a relationship between the level of education of parents with behavior held by adolescents $(\mathrm{p}=0.03)$, adolescents who have parents with primary or low education have a 4.91 chance. times to have health behaviors high risk reproduction compared to adolescents who have parents with a high education level. Parents should be the main source of information and educators on reproductive health, but what happens is that many parents find it difficult to talk about reproductive health issues.

The level of education possessed by most respondents in this study is in the high middle category, but does not affect the behavior of the respondents because of the lack 
of openness that is done either on the child or parent, this is supported by the results of research that states that both parents or adolescents rely on information provided by health professionals, they assume that health professionals are sources of information that convey accurately and factually, thereby minimizing adolescents searching for information or their own knowledge through the internet network.[7]

\section{The influence of parental communication on adolescent reproductive health behaviour}

Respondents who showed communication with their parents were $56.5 \%$, both respondents who stated there was communication or there was no communication with their parents did not affect. The test results show that parental communication on reproductive health behavior does not show any influence, this is seen from the value of $p=0.420$ and the value of $=^{2}=0.651$ by using a degree of error $(\alpha)$ of 0.05 , then $\mathrm{p}<\alpha(0.420>0.05)$. Communication between parents and children can be in the form of directives which include providing motivation to children, meeting the needs of children, religious education with the aim of understanding themselves and their environment so they are able to make responsible and controlling decisions that are not good and avoid deviant behavior. Parents often find it difficult to overcome doubts about starting a communication about reproductive health because they feel this is a sensitive talk and they lack the skills to talk about reproductive health.

This study mostly claimed that there was communication between respondents and parents, but most respondents claimed that there was very little mention of reproductive health or sexuality, this is in line with the results of research conducted by [8] showing that teenagers sometimes do not talk even though they want to talk to their parents, because they think that it is a taboo subject or problem that cannot be spoken with their parents and they assume that their parents and family do not have enough knowledge about reproductive health or sexuality

\section{E. The influence of parenting on adolescent reproductive health behaviour}

The results of the study stated that $53.5 \%$ of respondents received authoritarian parenting from their parents and $46.5 \%$ of respondents received democratic parenting from their parents. It can be concluded that parenting does not effect on reproductive health behavior, evidenced by the results of the chi-square test that the value of $p=0.590$ and the value of $=^{2}=0.290$ by using a degree of error $(\alpha)$ of 0.05 , then $\mathrm{p}<\alpha(0.707>0.05)$, respondent with a pattern neither authoritarian nor democratic fostering influence the respondent's behavior. In contrast to the results of [9] showed that there was a significant influence between parenting patterns of behavior with a coefficient of 0.628 with the meaning that increasing parenting patterns, the behavior will be better. Parenting is the relationship between children and parents guiding, educating, and disciplining children in accordance with existing norms in society.

According to the results of research [10], it states that in the southeastern Indian state, parenting style that is owned by parents based on culture is a significant predictor of risk taking sexual behavior possessed by adolescents. The difference in the results of this research is caused by the perspective or value held by different parents, so that in the way of educating or disciplining their children is also different, in addition to the parenting patterns held by parents tend to adjust to the environment around them, this is the cause of differences in the delivery of information.

\section{F. Factors that most influence adolescent reproductive health behaviour}

The results of the Multiple Logistic Regression test indicate that the factor that most influences adolescent reproductive health behavior is knowledge, this can be concluded from the results which state the value of $\mathrm{p}$ sig $=$ 0.003. According to [11] adolescent reproductive health knowledge can influence behavior premarital sex in adolescents in Indonesia. Behavior is not accompanied by sufficient knowledge accompanied by emotional levels that are still unstable can cause bad effects. Adolescent knowledge about reproductive health will affect adolescent behavior for healthy living[12], states that knowledge of reproductive health has an important role in shaping behavior, and is expected to be able to control behavior as it can filter out various information obtained by adolescents so as to reduce the negative impact that will be experienced by adolescents.

\section{CONCLUSIONS AND SUGGESTIONS}

Based on the results of research on adolescent reproductive health in Jombang Regency shows that:

1. There is an influence between the respondents' knowledge on adolescent reproductive health behaviors in Jombang, shown in the Chi-Square test with a value of $\mathrm{p}<\alpha(0,000<0.05)$

2. There is no influence between the attitudes of respondents towards adolescent reproductive health behavior in Jombang, indicated in the ChiSquare test with a value of $\mathrm{p}<\alpha(0.290>0.05 \mathrm{p}<\alpha$ $(0.707>0.05)$

3. There is no influence between the level of education of respondents' parents on adolescent reproductive health behavior in Jombang, indicated in the Chi-Square test with a value of $\mathrm{p}$ $<\alpha(0.861>0.05)$

4. There is no influence between communication with the respondent's parents on adolescent reproductive health behavior in Jombang, indicated in the Chi-Square test with a value of $\mathrm{p}$ $<\alpha(0.420>0.05)$

5. There is no influence between the parenting patterns of respondents' parents on adolescent reproductive health behaviors in Jombang, shown in the Chi-Square test with valuesp $<\alpha(0.707>$ $0.05)$

6. The factors that most influence the behavior of adolescent reproductive health in Jombang are tested using Multiple Logistic Regression with the result p sig $=0.003$. Score Odd Ratio (OR) is 0.413 which means that respondents with less knowledge have the risk or the possibility of good behavior by 0.413 times compared to respondents who have good knowledge, in other words 
respondents who have good knowledge have the possibility of good behavior by 2.42 times compared to respondents with less knowledge

Based on the result of this study, researcher propose the following suggestions:

For the Government

1. It is expected to increase various programs on reproductive health through the Department of Health, Non-Governmental Organizations, Educational Environments and Community Environments. For example, the health department together with medical personnel or health workers more often come to schools or villages to conduct coaching for peer counselors and conduct health promotion or counseling to adolescents.

For parents

2. Researchers hope that parents can be more open with children by providing information about adolescent reproductive health, providing adequate religious understanding.

For teens

3. Adolescents are expected to increase their knowledge and information about adolescent reproductive health but at the right source. Teens must be more careful in choosing friends.

\section{REFERENCES}

[1] H. Suyono, "Kesehatan Reproduksi Dan Keluarga Berencana: Implikasi Program Aksi Kairo Di Indonesia.," J. Reprod. Heal., vol. 8, no. 2, p. 66, 2016.

[2] Suharsa, "Kehidupan seksual remaja di daerah kumuh perkotaan Jakarta," vol. 8, pp. 26-30, 2016.

[3] S. Notoarmojo, Konsep perilaku kesehatan. Promosi Kesehatan, Teori Dan Aplikasi. Jakarta: Raneka Cipta, 2010.

[4] S. Azwar, Sikap Manusia: Teori Dan Pengukurannya. Jakarta, 2013.

[5] Hasanah, "Pemahaman Kesehatan Reproduksi Bagi Perempuan: Sebuah Strategi Mencegah Berbagai Resiko Masalah Reproduksi Remaja. Sawwa:," Stud. Gend., vol. 32, no. 2, pp. 163-151, 2017.

[6] M. Wawan, A., \& Dewi, "Teori dan Pengukuran Pengetahuan, Sikap dan Perilaku Manusia," Nuha Med., vol. 9, pp. 119-123, 2012.

[7] H. Morris, J. L., \& Rushwan, "Adolescent sexual and reproductive health: The global challenges. International," J Gynecol. Obstet., vol. 33, pp. 405-411, 2015.

[8] Basaran, "Information, Attitudes and Behaviours about Reproductive Health of a Unýversity's Students.," Int. J. Caring Sci., 2017.

[9] L. Arub, "Hubungan Pola Asuh Orangtua Dengan Perilaku Seksual Remaja di SMK NEGERI 1 SEWON BANTUL," Yogyakarta, 2017.

[10] Hueber, "Examining the relationship between adolescent sexual risk-taking and perceptions of monitoring, communication, and parenting styles. The Journal of Adolescent Health," Off. Publ. Soc. Adolesc. Med., vol. 33, no. 2, pp. 71-78, 2003.

[11] Z. Nasution, Komunikasi Pembangunan. Jakarta: Rajawali, 2012.

[12] Huver, "Personality and parenting style in parents of adolescents," J. Adolesc., vol. 33, no. 2, pp. 395-402, 2010. 